\title{
FACTORS DETERMINING THE EFFICIENCY AND EFFECTIVENESS OF PUBLIC E-ADMINISTRATION
}

\section{AGNIESZKA AGATA TOMASZEWICZ}

University of Szczecin, POLAND

e-mail: agnieszka.tomaszewicz@wzieu.pl

RECEIVED
ACCEPTED
JEL
CLASSIFICATION

KEYWORDS

ABSTRACT
10 June 2018

13 September 2018

$\mathrm{H} 11, \mathrm{M} 00, \mathrm{M} 15$

performance of government, Business administration, IT Management, e-administration

In recent years, the role of public administration has been constantly changing. The requirements concerning the improvement of the business successive to the administration are increasing. The transformation of the economic system forces the processes of institutional, functional and instrumental improvement of public administration. The reason for this state of affairs is the growing expectations of citizens about the quality of public services and their simultaneous opposition to raising taxes. As indicated in the article, the administration's action is to support effective and effective e-government.

It has been specified that the basis of the development of effective e-administration lies in the human factor, which should contribute to increasing demand (through education) and supply (by building content) to the e-services it provides. It follows that successful implementation of the desired e-services depends on the level of e-skills of all entities involved in the planned project.

It was concluded that in order to be able to achieve a higher level of e-administration development, we need an efficient, effective, transparent and open model of its development, which will contribute to the increase of accessibility and the level of advancement of public services over the Internet. This model must take into account the needs, expectations and preferences of both citizens and the offices themselves.

\section{Introduction}

There is a perception that a traditional, procedure-oriented public administration model should be replaced with result-oriented administration. The use of information and communication technologies (ICT) is an activity that significantly improves the functioning of government administration. Thanks to their development and the constantly growing access to them, the importance of electronic administration (e-government) is systematically growing. 


\section{Litepature review}

Electronic public administration (e-administration) is treated as a 'mechanism that ensures cooperation between officials of public administration units in order to fulfill collective needs of clients' (Minkowski, Motek, Perdał, 2009 , p. 8). This term is also often referred to as the use of information and telecommunications technologies in public administration, in conjunction with organizational changes and acquiring new skills to improve the quality of public services, strengthen citizens' involvement in democratic processes and support for state policy' (Eurostat, 2007; Grodzka, 2009, p. 58).

It is often remarked that a new approach to e-administration means that management instruments should also be effectively used in the public sector. The concept of new public management also means taking control of bureaucracy and passing it on to local communities and integrating activities of all sectors (public, private and social sector). This result in improved government actions and increased interest in the issues of improving operational efficiency, measured by the 'ratio of material inputs to the achieved effect' (Leoński, 2004, p. 62), and the reduction of administration costs (Grycuk, 2011, p. 1).

Effective public e-government is therefore one that is managed through objectives and draws attention to the quality of the office's policy, creates a clear division of competences and responsibilities among employees, defines proper administrative procedures, creates the right communication between individual organizational units. Among these tools, there should also be clear criteria for striving to achieve the adopted goals, and include, among others, availability, information, competence, speed and reliability as well as the main principles of operation, such as legality, expediency and effectiveness of administrative activities.

In the new paradigm of functioning of e-administration, it is important to assess to what extent a public institution fulfills its tasks in a way (Noga, Bogucki, Paluszyński, 2011):

- effective - means using well-justified, low expenditures,

- efficient- compatible with social demand.

These elements are also the basis for the development and provision of public e-services.

The premise for improving the efficiency of e-administration is to increase efficiency in acting as a whole and to achieve the intended results in the sphere of public tasks. It is also worth noting that the lack of sufficient information system efficiency is defined as one of the factors determining the efficiency of the organization's operation, including the public institution and requires a comprehensive understanding of the barriers to effectiveness (Niedźwiedziński, 2004, p. 115).

The effectiveness of e-administration depends primarily on the human factor that determines it by influencing the level of competence and motivation of the staff employed in public administration. The level of competence determines the efficiency of management systems, and the rationality of decisions is influenced by staff with the right skills. Therefore, an important factor translating into the approach and increase in the use of e-public administration is the implementation of employee training to improve their IT skills. The incentive system in administration should therefore be structured in such a way as to result in identifying individual employee goals with the goals of the local community.

In turn, the determinant of the efficiency of the ICT system in e-administration is the level of satisfaction and fulfillment of the user's needs (Zakrzewski, Stroińska, 2007, p. 114). Through the use of electronic data exchange and documents of the government and self-government administration units, efforts should strive to increase the efficiency of their functioning. Efficiency, as well as the speed of document processing by offices and the efficiency 
of information exchange between administration units and the public through the use of ICT tools, are expected to become decisive factors for an efficient office, and should translate into economic development of the country. Programs created under e-administration, thanks to unlimited time (24 hours / day) availability of some functions translate into effective use of time. They concern both office employees and potential clients (Laskowski, 2005, pp. 79-80).

Among the decisive factors in the effectiveness of e-administration, among others, are savings, reorganization and back-office integration, interoperability, skills and knowledge, data exchange and re-use, as well as a change in the world view of citizens (Podręcznik..., 2007, p. 15).

The effectiveness of e-administration depends on the integration process and should be focused around social dialogue and increasing public value along with engaging in public services (Podręcznik..., 2007, p. 27). According to the World Economic Forum, in the future it will be the main condition for the creation of administration, and means that it should be FAST, that is flatter, agile, streamlined and Tech-enabled. The following factors stand out among the factors that are decisive for the effectiveness of e-administration: simplification of administrative procedures, increase of front-office points, transparency of its functioning, and currently important citizens' participation in content creation and involvement in services (Noga, Bogucki, Paluszyński, 2011). These and other factors are presented in Table 1.

Tahle 1. Factors of effective e-administration

\begin{tabular}{ll}
\hline & Simplifying procedures/reducing the administrative burden \\
\cline { 2 - 2 } $\begin{array}{l}\text { E-government effectiveness } \\
\text { factors include }\end{array}$ & Transparency, credibility, responding to needs \\
\cline { 2 - 2 } & An increase in public value \\
\cline { 2 - 2 } & Multi-channel approach \\
\hline & Integration and involvement in services \\
\hline
\end{tabular}

Source: Podręcznik... (2007), p. 29.

However, the basis for effectiveness in the process of creating good administration is to achieve a state consistent with the intended goal, taking into account the optimization of side effects and procedures for responding to unpredictable effects (Diagnoza, 2008, p. 29). In the face of these data, efficiency, effectiveness and democracy form the basic foundations of creation and the framework for measuring well-functioning e-government.

In the case of measures of the effectiveness of the office's functioning, there is a level of efficiency of service for the clients, measured, among others, the level of their satisfaction with the service.

Among the further factors that allow creating conditions for the development of e-administration is the complementarity of e-services. In this context, it is important to strengthen the citizens' ability to engage online. The wider and less diverse the access of citizens to the Internet and the greater the possibility of engaging them online, the easier it is to take advantage of the potential of new public e-services.

Taking into account the essence of e-administration, it is assumed that for the proper implementation of e-administration, in addition to the already mentioned elements, it is first and foremost (based on: Polska 2030. Trzecia..., 2012, pp. 101-103; Boni, 2009): 
- support investments in broadband infrastructure to ensure universal, high-quality Internet access,

- to build digital competences, implement universal digital education and create a modern network infrastructure,

- to develop open standards for the provision of public information, taking into account legal, technical and financial issues, in order to ensure, among others, the possibilities of digital information processing,

- introduce a repository system that will make information resources available to public administration in an open, optimal and standardized manner,

- reduce regulatory barriers hindering the sale of goods and provision of services by electronic means,

- conduct systematic digitization of resources created and collected in non-electronic form.

In the era of growing public awareness and the development of new public management, the role of the state and local governments must be revised, incorporating the shaping of strategies, mechanisms of development and standardization in a new form (http://archiwum-ukie.polskawue.gov.pl). The application of standards creates the possibility of comparing the parameters of services provided with the applicable standards, and their lack prevents control of local government budgets on the basis of the effectiveness criterion (Kulesza, 2005, p. 35). Therefore, standardization is defined as one of the key factors responsible for the proper development of e-government administration.

The increase in the use of public e-administration, in addition to the factors already described, is also determined by the number of Internet users and the development of social tools that often allow citizens to consult decisions, participate at every decision-making stage or even codecision through the involvement of citizens.

More precisely, it can be said that the efficient development of e-administration also requires actions to:

- consolidation and ensuring cooperation between individual public administration bodies,

- ensuring adequate standards of public administration systems and their cross-border nature,

- strengthening the management and coordination of information systems,

- effective use of structural funds that will support the construction of e-government,

- cooperation with particular levels of public administration units in order to facilitate the flow of information, achieve synergy of action, avoid duplication of errors and even out the development of electronic administration,

- cooperation of the public and private sectors with the scientific community in order to create a national program for research and development of the information society.

The development of e-administration is still limited by barriers that slow down the promotion of electronic services. Among them is the lack of appropriate organizational regulations, lack of infrastructure or lack of education in the use of ICT and the preparation of the community to use the possibilities of e-administration. What also matters here is the skeptical attitude and often the reluctance of office staff to technological changes, their accustom to the paper flow of documents and the procedures used so far (Kasprzyk, 2011, p. 347; Oddziaływanie, 2007, p. 41).

The lack of fast growth of Internet users is still a significant obstacle to the implementation of e-administration. This is often conditioned by low skills, lack of motivation and the need to use it, and the availability of infrastructure.

The constant lack of effective system mechanisms for creating digital competences and the low level of availability of relevant content and public services corresponding to the needs of users, including potential users, result in a low interest of citizens in the e-government offer. These users, as mentioned above, simply do not see the reasons to use these services (Polska 2030. Trzecia..., 2012, p. 100). 
The process of computerization of public administration through its specificity according to B. Grabowa will be slower than in private institutions. The reasons for such a state are mainly due to: the universality of administration activities, a wide group of recipients, multiplicity and the complex, often individual nature of the products and services provided. The barrier of e-administration is high implementation costs, which e-business accounts for in the prices of products (goods, services), while e-administration has to calculate in budgets, often spreading them over several years (Grabow, 2002, p. 3; Kaczmarek, 2005, p. 335).

Building public e-administration requires the existence of appropriate legal, economic or infrastructural conditions that will enable easier implementation of public administration tasks. Solutions used in e-administration should be consistent with each other and provide a common system of public information and services made available to the public.

The above means that the development of electronic public administration requires the implementation of interoperable, standardized, effective and effective, oriented to the priorities of the local community organizational solutions supported by information and communication technologies.

The development of public e-administration through continuous improvement of it should be easier to adapt to new IT solutions, because it depends on them. It should also ensure the openness of the administration, which allows to ensure the openness of the stakeholders' service, through the openness of teleinformation services. These activities, conditioning the efficiency of the model should be supported:

- creating open standards that will enable interoperability to be applied in the process of handling stakeholders and providing services/e-services to solutions and related systems;

- ensuring the usability and transparency of the stakeholder service process;

- efficiency of the process of handling the stakeholders and implementation of e-services through completeness and accuracy achieved at individual levels, as well as in the entire model;

- effectiveness of e-administration, which is related to the implementation by users of the objectives set in the model, depending on the process of interoperability.

\section{Conclusions}

Proper use of e-government solutions introduced in offices should improve the service for both citizens and the offices themselves, including in particular:

- improving the quality of services provided,

- shortening the time of customer service,

- improving the punctuality of the official matter being dealt with,

- improving the image of the office,

- whether the complexity of meeting their needs is particularly demanded by clients.

In Poland, the process of integrating electronic administration systems is just underway. Offices provide their services with the help of several different websites, which is associated with their inefficiency and thus low efficiency in servicing local communities.

In order to achieve a higher level of e-administration development, it is necessary to create an efficient, effective, transparent and open model of its development, which will contribute to the increase of accessibility and the level of advancement of public services over the Internet. This model must take into account the needs, expectations and preferences of both local communities and the offices themselves. 
The construction and continuous improvement of the local government e-government development model and the implementation of specific activities recommended for this purpose will contribute to improving the service of local communities, which in turn will improve the quality of their lives.

\section{References}

Boni, M. (ed.) (2009). Polska 2030. Wyzwania rozwojowe. Warszawa: Kancelaria Prezesa Rady Ministrów.

Diagnoza barier technologiczno-prawnych w zakresie informatyzacji lokalnej i regionalnej administracji samorządowej i ich wpływ na zdolność wykonywania zadań publicznych oraz rekomendacje rozwiazań prawnych i technologicznych (2008). Warszawa: Fundacja Rozwoju Demokracji Lokalnej.

Eurostat. Retrieved from: http:/lec.europa.eu (6.05.2007).

Grabow, B. (2002). E-govenment: umfassande Modernisierungsaufgabe. Difu-Berichte, 4.

Grodzka, D. (ed.) (2009). Społeczeństwo Informacyjne. Studia BAS, 3 (19).

Grycuk, A. (2011). Lean Government, czyli koncepcja szczupłego zarządzania w administracji publicznej. Analizy BAS, 3 (47) .

Kaczmarek, T. (2005). Struktury terytorialno-administracyjne i ich reformy w krajach europejskich. Poznań: Wydawnictwo Naukowe UAM.

Kasprzyk, B. (2011). Aspekty funkcjonowania e-administracji dla jakości życia obywateli. Retrieved from: http://www.univ.rzeszow.pl/ file/15858/027.pdf.

Kulesza, M. (2005). Potrzebne standardy świadczenia usług publicznych. Gazeta Samorządu i Administracji, 11.

Laskowski, P. (2005). Technologie informatyczne a zarządzanie w e-administracji samorządowej. Wałbrzyska Wyższa Szkoła Zarządzania i Przedsiębiorczości. Retrieved from: http://kmis.pwsz.chelm.pl/publikacje/IV/Plaskowski.pdf (20.04.2011).

Leoński, Z. (2004). Nauka administracji. Warszawa: C.H. Beck.

Minkowski, A., Motek, P., Perdał, R. (2009). Poziom zaawansowania wielkopolskich urzędów gmin w zakresie informatyzacji i rozwoju elektronicznych usług publicznych. Poznań: Wydawnictwo M-Druk.

Niedźwiedziński, M. (2004). Globalny handel elektroniczny. Warszawa: Wydawnictwo naukowe PWN.

Noga, M., Bogucki, D., Paluszyński, W. (2011). Stan prac nad informatyzacją Państwa, materiały konferencyjne. Retrieved from: http:// konferencja2011.mwi.pl/phocadownload/prezentacje_sroda/bogucki_-noga.pdf.

Oddziaływanie inwestycji ICT na rozwój regionalny. Aspekty społeczne i ekonomiczne (2007). Warszawa-Tarnów: Akademia e-Rozwoju Regionalnego, Stowarzyszenie "Miasta w Internecie".

Podręcznik dobrych praktyk regionalnych. e-administracja (2007). Tarnów: Europejskie Regionalne Stowarzyszenie Społeczeństwa Informacyjnego, Projekt IANIS był współfinansowany ze środków Dyrekcji Generalnej ds. Polityki Regionalnej Komisji Europejskiej, Opracowanie wersji polskiej: Stowarzyszenie „Miasta w Internecie”.

Polska 2030. Trzecia fala nowoczesności. Długookresowa Strategia Rozwoju Kraju (2012). Warszawa: Ministerstwo Administracji i Cyfryzacji.

World Economic Forum „Future of Government - Lessons learned around the World 2011”.

Zakrzewski, L., Stroińska, E. (2007). Miejsce i rola człowieka w systemie informacyjnym. In: T. Grudniewski, J.M. Olchowiak (eds.), Przetwarzanie informacji w społeczeństwie informacyjnym. Biała Podlaska: Państwowa Wyższa Szkoła zawodowa im. Papieża Jana Pawła II w Białej Podlaskiej.

Cite this article aS: Tomaszewicz, A.A. (2018). Factors determining the efficiency and effectiveness of public e-administration. European Journal of Service Management, 3 (27/1), 341-346. DOI: 10.18276/ejsm.2018.27/1-43. 